\title{
MOTIVASI BELAJAR MAHASISWA TEKNOLOGI PENDIDIKAN DALAM PEMBELAJARAN ONLINE
}

\author{
Nala Nafilata Fadilah, Punaji Setyosari, Susilaningsih \\ Jurusan Teknologi Pendidikan, Fakultas Ilmu Pendidikan, Universitas Negeri Malang \\ Jalan Semarang 5 Malang 65145 0341-574700 \\ Nnafilata97@gmail.com
}

Article History

Received:20 Agustus 2020, Accepted: 19 November 2020, Published: 26 Februari 2021

\begin{abstract}
Abstrak
Penelitian ini bertujuan untuk mendeskripsikan motivasi belajar dan mengetahui faktor motivasi belajar dalam pembelajaran online mahasiswa jurusan Teknologi Pendidikan Universitas Negeri Malang. Motivasi belajar merupakan sebuah penggerak dalam diri peserta didik untuk melakukan pembelajaran sehingga mencapai tujuannya. Penelitian ini menggunakan metode penelitian kuantitatif deskriptif dan menggunakan kuesioner berbentuk pernyataan dengan menggunakan skala likert, yang kemudian dianalisis menggunakan persentase, dari hasil akhir analisis kemudian dideskripsikan. Subjek penelitian ini adalah semua mahasiswa Teknologi Pendidikan angkatan 2017 yang telah mengikuti pembelajaran online. Pada hasil penelitian motivasi belajar dalam pembelajaran online berada pada kategori positif, sedangkan untuk hasil penelitian faktor motivasi belajar dalam pembelajaran online berada pada kategori positif, tidak semua mahasiswa memiliki motivasi belajar yang baik. Oleh karena itu, motivasi belajar mahasiswa dapat ditingkatkan kembali dengan mengatasi beberapa faktor pemghambat motivasi belajar supaya motivasi belajarnya meningkat sehingga tujuan belajarnya tercapai.
\end{abstract}

Keyword: Motivasi Belajar dalam Pembelajaran Online

\begin{abstract}
This study aims to describe the motivation to learn and to determine the factors of learning motivation in online learning for students majoring in Educational Technology, State University of Malang. Motivation to learn is a driving force in students to carry out learning so as to achieve their goals. This research uses descriptive quantitative research methods and uses a questionnaire in the form of a statement using a Likert scale, which is then analyzed using a percentage, the final results of the analysis are then described. The subjects of this study were all 2017 Educational Technology students who had participated in online learning. In the research results, learning motivation in online learning is in the positive category, while for the research results the learning motivation factor in online learning is in the positive category, not all students have good learning motivation. Therefore, student learning motivation can be improved again by overcoming several inhibiting factors of learning motivation so that learning motivation increases so that learning objectives are achieved.
\end{abstract}

Keyword: Development, multimedia tutorial, solar system 


\section{PENDAHULUAN}

Motivasi belajar dalam diri peserta didik dapat dilihat dari tindakan peserta didik dalam belajar, (Sanjaya, 2006) Motivasi ialah dorongan atau dukungan dari dalam yang membuat peserta didik bertindak dalam mengerjakan sesuatu di saat kondisi yang membutuhkan, (Suprihatin, 2015) sekuat apapun motivasi yang dikuasai individu peserta didik akan banyak menguatkan karakter perilakunya dalam segala konteks terutama saat kegiatan belajar. Motivasi peserta didik yaitu tanggung jawab pendidik, pendidik harus memiliki kemampuan pedagogis untuk menyelesaikan keinginan utama belajar peserta didik saat proses belajarnya (Athoillah, 2019).

Pada lingkup dunia pendidikan, belajar merupakan kegiatan utama. Untuk menunjukkan berhasil atau tidaknya keinginan utama belajar peserta didik tergantung motivasi belajar peserta didik saat mengikuti kegiatan belajar. Motivasi belajar ketika kegitan belajar sangat penting untuk menyukseskan sasaran utama peserta didik. Seperti pendapat (Pusvyta Sari, 2015) motivasi belajar peserta didik penting untuk menciptakan keadaan dalam menyelesaikan sasaran pembelajaran. (Djuniadi, 2013) membagi motivasi belajar menjadi 2 yaitu instrinsik, motivasi nan muncul dari individu peserta didik itu sendiri dan motivasi ekstrinsik motivasi nan terpengaruhu oleh lingkungan luar peserta didik. Terdapatnya motivasi dalam individu peserta didik dapat mempermudah untuk menciptakan pembelajaran. Sedangkan apabila motivasi belajar dalam individu peserta didik rendah, kualitas belajarnya akan rendah. Seperti pendapat (Ibrahim \& Suardiman, 2014) melakukan tindakan nan mendukung adanya suatu dorongan atau kemauan yang tinggi, maka akan memperoleh hasil yang memuaskan, begitupun sebaiknya.

Meskipun motivasi belajar sangat perlu untuk peserta didik, motivasi belajarpun memiliki faktorfaktor yang membuat motivasi itu ada. Faktor - faktor motivasi belajar tersebut menurut (Laely, 2020) ada tiga macam, yaitu : faktor internal, faktor eksternal dan pendekatan belajar siswa. (Sudaryono, 2012) faktor pembantu motivasi belajar contohnya seperti : cita-cita peserta didik, kondisi diri peserta didik, kondisi lingkungan, unsur-unsur dinamis dan upaya pendidik dalam mengajar. Peserta didik mempunyai motivasi tinggi ditunjukkan dengan memiliki rasa semangat untuk ikut serta dalam pembelajaran online, dan mempunyai kemauan belajar amat tinggi. Sedangkan peserta didik mempunyai motivasi belajar rendah dapat dipantau dari cara menggunakan waktunya saat ikut serta dalam pembelajaran online, dan kurang percaya diri dengan apa yang dilakukannya.

Mengenai dengan terciptanya teknologi masa kini yang bertambah meningkat (Effendi \& Wahidy, 2019) berpendapat bahwa semua pihak yang terjun dalam dunia pendidikan harus dapat mengimbangi dan mengikuti kemajuan teknologi. Dapat diperhatikan pada lingkungan sekarang kemajuan teknologi sangat didukung dengan tersedianya jaringan internet yang bisa memberikan banyak perkembangan terutama dalam lingkup dunia pendidikan. Dalam pendidikan, internet di manfaatkan untuk media pendukung penggunaan model pembelajaran yang bisa dibilang pembelajaran online.

Pembelajaran online merupakan tindakan belajar dengan menggunakan teknologi elektronik sebagai alat untuk melangsungkan pembelajaran (Sabar \& Rahman, 2011). Pembelajaran online bisa dikatakan pembelajaran jarak jauh dengan dalam jaringan dimana pendidik dan peserta didik tidak berjumpa secara langsung dengan pendidik. Sasaran pembelajaran online pun bisa menambah pengetahuan dan keterampilan nan bisa disalurkan berkaitan dengan membantu individu guna mewujudkan tujuan pembelajarannya (Setyosari, 2007). Terdapatnya pembelajaran online membantu pendidik ketika berkomunikasi dengan peserta didik mengenai materi yang sedang diajarkan.

Penerapan model pembelajaran online tersebut sangat membantu pendidik dalam mengajar untuk memberikan peserta didik wawasan yang luas tidak hanya lingkup tempat belajar seperti dikelas saja. 
(Adijaya \& Santosa, 2018) Ada beberapa masalah ketika berlangsungnya pembelajaran online seperti materi ajar, interaksi belajar dan lingkungan belajar.

Berdasarkan wawancara dari sebagian mahasiswa Teknologi Pendidikan Universitas Negeri Malang diperoleh informasi mahasiswa paling termotivasi ketika mengikuti mata kuliah yang menerapkan pembelajaran online sebagai metode pembelajaran, akan tetapi tidak fokus ketika pembelajaran. Hal tersebut bisa diperhatikan dari setiap permasalahan saat mengikuti kegiatan pembelajaran online seperti ketika mahasiswa mendapatkan tugas diluar kelas melalui web maupun link yang dibagikan ke mahasiswa seringkali banyak yang meremehkan karena diberi waktu pengumpulan atau pengerjaan yang terlalu panjang, mahasiswa masih membutuhkan pengarahan dari dosen secara langsung atau tatap muka, mahasiswa memanfaatkan waktu belajar untuk bermain dengan menyalahgunakan internet untuk mencari hal yang di luar pelajaran ketika pembelajaran online berlaku di dalam kelas.

Motivasi belajar mahasiswa Teknologi Pendidikan Universitas Negeri Malang ketika ikut serta dalam pembelajaran online sangat beragam, ada yang memiliki motivasi tinggi dan motivasi rendah. Tinggi rendahnya motivasi belajar peserta didik dikarenakan oleh beberapa faktor, seperti fasilitas dalam belajar, lingkungan dalam belajar, kondisi keluarga.

Diperhatikan dari berbagai permasalahan diatas keadaan seperti itu berpengaruh terhadap hasil belajar mahasiswa sehingga perlu adanya penanganan yang dilakukan untuk mendorong mahasiswa agar termotivasi belajar dalam penerapan pembelajaran online.

\section{METODE}

Penelitian ini menggunakan pendekatan kuantitatif deskriptif, guna mendeskripsikan motivasi belajar dan faktor motivasi belajar. Karena dengan menetapkan metode kuantitatif deskriptif dapat mendeskripkan hasil penelitian dengan angka maupun kata-kata. Subjek penelitian ini sejumlah 98 mahasiswa Teknologi Pendidikan angkatan 2017. Untuk mengukur respon atau pendapat mahasiswa, peneliti menetapkan instrumen berupa kuesioner dengan mengacu pada beberapa indikator motivasi belajar yang dijabarkan oleh (Uno, 2008) dan dirujuk (Ramadhon et al., 2017) dalam jurnalnya motivasi belajar, yaitu : adanya hasrat dan keinginan untuk berhasil, adanya kegiatan nan menarik dalam belajar, adanya harapan dan cita-cita di masa depan, adanya lingkungan belajar yang kondusif, adanya dorongan dan kebutuhan dalam belajar, dan adanya penghargaan dalam belajar. Dan indikator faktor pendorong dan pengahambat motivasi belajar pembelajaran online mengacu pada beberapa indikator yang dijabarkan (Sabrina et al., 2017) yaitu : kondisi lingkungan belajar, kemampuan mahasiswa, pemanfaatan waktu dalam belajar, aspirasi Mahasiswa, dan upaya dosen dalam mengajar. Angket yang dibagikan sebanyak 40 butir pernyataan dan menentukan skor menggunakan Skala Likert. Data yang didapatkan pada saat pengumpulan data akan dianalisis menggunakan persentase dan kemudia dideskripsikan.

Perolehan persentase diambil dari nilai hasil yang didapat pada setiap indikator yang digunakan. Pada penelitian ini menyesuaikan pedoman dari (Sugiyono, 2011) yang juga digunakan dalam jurnalnya (Al Aslamiyah et al., 2019) yaitu semakin tinggi nilai persentase maka semakin tinggi juga persepsi responden. Sedangkan untuk meringkas hasil data perolehan penelitian menggunakan ketentuan skala persentase interpretasi hasil menurut (Dolet, 2013).

\section{HASIL}

Perkembangan penelitian motivasi belajar mahasiswa dalam pembelajaran online mengacu pada beberapa indikator yang dijabarkan oleh (Uno, 2008) dan dirujuk (Ramadhon et al., 2017)dalam jurnalnya motivasi belajar. Pengambilan data penelitian ini ditujukan pada mahasiswa jurusan Teknologi Pendidikan angkatan 2017 dengan jumlah responden 98 mahasiswa. Data skor perolehan penelitian ini adalah sebagai berikut : 
Tabel 1. Analisis Motivasi Belajar Mahasiswa dalam Pembelajaran Online

\begin{tabular}{cccc}
\hline $\mathbf{N}$ & Indikator & Persentase & Kategori \\
\hline 1. & Adanya hasrat dan keinginan berhasil & $75,38 \%$ & Positif \\
\hline 2. & Adanya kegiatan menarik dalam belajar & $73,27 \%$ & Positif \\
\hline 4. & Adanya harapan dan cita-cita masa depan & $73,77 \%$ & Positif \\
\hline $\mathbf{5 .}$ & $\begin{array}{c}\text { Adanya lingkungan belajar yang kondusif } \\
\text { belajar }\end{array}$ & $67,02 \%$ & Positif \\
\hline & Total Persentase & $68,62 \%$ & Positif \\
\hline
\end{tabular}

Hasil perolehan data analisis motivasi belajar mahasiswa dalam pembelajaran online bisa diperhatikan pada tabel 1 analisis motivasi belajar mahasiswa dalam pembelajaran online. Dari perolehan data yang tertera pada masing-masing indikator mendapatkan hasil persentase yang berbedabeda dengan kategori yang sama. Keseluruhan data penelitian perihal motivasi belajar dalam pembelajarn online ini memiliki total persentase berbilang 71,72\% tergolong dalam golongan positif, yaitu tidak semua mahasiswa mempunyai motivasi belajar dalam pembelajaran online dengan sempurna.

Sedangkan hasil penelitian mengenai faktor pendukung dan faktor penghambat motivasi belajar pada pembelajaran online mengacu pada beberapa indikator yang dijabarkan oleh (Sabrina et al., 2017). Berikut data skor perolehannya disajikan pada tabel 2.

Tabel 2. Analisis Faktor Pendukung dan Penghambat Motivasi Belajar Mahasiswa dalam Pembelajaran Online

\begin{tabular}{clcc}
\hline N & \multicolumn{1}{c}{ Indikator } & Persentase & Kategori \\
\hline 1. & Kondisi lingkungan belajar & $67,21 \%$ & Positif \\
\hline 2. & Kemampuan mahasiswa & $70,74 \%$ & Positif \\
\hline 3. & Pemanfaatan waktu dalam belajar & $67,68 \%$ & Positif \\
\hline 4. & Aspirasi mahasiswa & $64,11 \%$ & Positif \\
\hline 5. & Upaya dosen dalam mengajar & $70,36 \%$ & Positif \\
\hline & Total Persentase & $\mathbf{6 8 , 3 5 \%}$ & Positif \\
\hline
\end{tabular}

Hasil perolehan data analisis faktor pendukung dan faktor penghambat motivasi belajar mahasiswa dalam pembelajaran online bisa diperhatikan pada tabel 2 analisis faktor pendukung dan penghambat motivasi belajar mahasiswa dalam pembelajaran online. Dari perolehan data terbilang masing-masing indikator mendapatkan hasil persentase yang berbeda-beda dengan kategori yang sama, dari 5 indikator di atas, indikator faktor penghambat motivasi belajar ada 2 yaitu pemanfaatan waktu dalam belajar dan aspirasi mahasiswa, sedangkan sisanya tergolong kedalam indikator faktor pendukung motivasi belajar. Keseluruhan data penelitian mengenai faktor pendukung dan penghambat motivasi belajar dalam pembelajarn online ini memiliki total persentase berbilang 68,35\% tergolong dalam golongan positif, yaitu tidak semua mahasiswa mempunyai faktor pendukung maupun faktor penngahambat motivasi belajar dalam pembelajaran online dengan sempurna.

\section{PEMBAHASAN}

Setelah melakukan analisis data dari hasil penelitian tetang motivasi belajar dan faktor pendukung dan penghambat motivasi belajar mahasiswa jurusan Teknologi Pendidikan dalam pembelajaran online masuk dalam golongan positif, bisa dicermati pada hasil persentase setiap indikator terbilang positif dengan total skor persentase keseluruhan indikator motivasi belajar sebesar 71,72\% dan skor presentase keseluruhan indikator faktor motivasi belajar sebesar 68,35\%. Dengan penjelasan hasil setiap indikatornya berikut ini :

Pada tabel 2 hasil analisis motivasi belajar dalam pembelajaran online mahasiswa Teknologi Pendidikan diatas, persentase pada indikator adanya hasrat dan keinginan dalam belajar memperoleh skor 1182 dengan 1568 skor maksimal sehinggan hasil persentase berbilang 75,38\% yang dapat diartikan pada indikator adanya hasrat dan keinginan dalam belajar dikategorikan positif. Dari hasil 
analisis tersebut menjelaskan bahwasanya dalam pembelajaran online mahasiswa ikut serta dalam pembelajaran secara sungguh-sungguh, yang demikian merupakan motivasi internal dimana mahasiswa mempunyai kesadaran sendiri ketika belajar. (Anggraini,2016) Motivasi internal merupakan motivasi yang tercipta dari kesadaran diri sendiri atas seberapa peningnya belajar untuk membuat diri menjadi lebih bisa.

Pada tabel 2 hasil analisis motivasi belajar dalam pembelajaran online mahasiswa Teknologi Pendidikan diatas, persentase pada indikator adanya kegiatan yang menarik dalam belajar memperoleh skor 1149 dengan 1568 skor maksimal sehinggan hasil persentase berbilang 73,27\% yang dapat diartikan pada indikator adanya kegiatan menarik dalam belajar dikategorikan positif. Dari hasil analisis tersebut menjelaskan bahwasanya dalam pembelajaran online mahasiswa ikut serta dalam pembelajaran online memiliki gaya belajar sendiri, dengan terciptanya variasi model belajar mahasiswa lebih menyukai pembelajaran dengan menggunakan gaya mereka masing-masing. (Wahyuni, 2017) Setiap mahasiswa memguasai gaya belajar visual, auditorial dan kinestetik namun tidak semuanya bergerak secara seimbang melainkan ada yang mengunggulkan gaya belajar yang dimilikinya, hal itu yang membuat mahasiswa menyukai pembelajaran yang memiliki variasi bermacam-macam dan sesuai dengan gaya belajar yang dikuasai mahasiswa.

Pada tabel 2 hasil analisis motivasi belajar dalam pembelajaran online mahasiswa Teknologi Pendidikan diatas, persentase pada indikator adanya harapan untuk berhasil dalam belajar memperoleh skor 1446 dengan 1960 skor maksimal sehinggan hasil persentase berbilang 73,77\% yang dapat diartikan pada indikator adanya harapan untuk berhasil dalam belajar tergolong positif. Dari hasil analisis tersebut menjelaskan bahwasanya sebagian mahasiswa mempunyai motivasi belajar yang semakin meningkat sehingga memiliki rasa semangat untuk tambah berantusias atau tidaknya mahasiswa ketika dalam menggapai sasaran belajar ditentukan oleh tingginya motivasi yang dimiliki. Seperti (Emda, 2018) terdapatnya motivasi pada setiap individu memberikan semangat sehingga mahasiswa mengetahui arah kemana tujuan belajarnya akan tercapai.

Pada tabel 2 hasil analisis motivasi belajar dalam pembelajaran online mahasiswa Teknologi Pendidikan diatas, persentase pada indikator adanya lingkungan belajar yang kondusif memperoleh skor 1051 dengan 1568 skor maksimal sehinggan hasil persentase bernilang 67,02\% yang dapat diartikan pada indikator adanya lingkungan belajar yang kondusif dikategorikan positif. Dari hasil analisis tersebut menjelaskan bahwasanya sebagian mahasiswa mempunyai motivasi belajar yang besar ketika mereka belajar sendiri dari pada bersama teman-temannya dengan seperti itu bisa diartikan bahwa lingkungan pertemanan bisa memicu motivasi belajar mahasiswa. (Devica, 2015) Lingkungan sekitar mahasiswa khususnya teman sebaya dapat menjadi penyebab seperti apa motivasi belajar yang pada akhirnya dapat memicu hasil belajar mahasiswa itu sendiri, karena peran teman sebaya merupakan salah satu faktor penting dalam menciptakan motivasi pada diri mahasiswa.

Pada tabel 2 hasil analisis motivasi belajar dalam pembelajaran online mahasiswa Teknologi Pendidikan diatas, persentase pada indikator adanya dorongan dalam belajar memperoleh skor 1076 dengan 1568 skor maksimal sehingga hasil persentase berbilang 68,62\% yang bisa diartikan pada indikator adanya dorongan dalam belajar dikategorikan positif. Dari hasil analisis tersebut menjelaskan bahwasanya sebagian mahasiswa mempunyai motivasi semangat yang besar ketika belajar dengan terwujudnya penerapan model pembelajaran online. Dengan itu terlihat mereka menyukai model pembelajaran online, sebab dengan terwujudnya hal tersebut mahasiswa merasa pembelajarannya bervariasi sehingga tidak menciptakan rasa jenuh dengan model pembelajaran itu-itu saja. (Sulisworo \& Agustin, 2017) Pembelajaran menggunakan model pembelajaran online dapat dijadikan variasi pembelajaran yang mampu mengurangi kejenuhan peserta didik dan mampu merangsang keterampilan berpikir kritis dan belajar mandiri sehingga peserta didik tertarik untuk bersungguh-sungguh dalam memecahkan masalah yang terdapat dalam materi pelajaran saat pembelajaran online.

Pada tabel 3 hasil analisis faktor motivasi belajar dalam pembelajaran online mahasiswa Teknologi Pendidikan diatas, pada indikator kondisi lingkungan belajar memperoleh skor 1054 dengan 1568 skor maksimal sehinggan hasil persentase berbilang 67,21\% yang dapat diartikan pada indikator 
kondisi lingkungan belajar dikategorikan positif. Hasil analisis tersebut menjelaskan bahwasanya sebagian mahasiswa merasa bahwa lingkungan belajar kala pembelajaran online merupakan bagian dari faktor pendukung proses belajar, seperti dengan terwujudnya fasilitas yang sudah tersedia mahasiswa merasa sangat terfasilitasi ketika belajar terutama pada saat pembelajaran online dengan tersedia akses wifi buat belajar. (Rahmawati et al., 2017) fasilitas yang ada pada ruang atau tempat belajar dapat dibilang faktor yang memicu kegiatan belajar.

Pada tabel 3 hasil analisis faktor pendukung dan penghambat motivasi belajar dalam pembelajaran online mahasiswa Teknologi Pendidikan diatas, pada indikator kemampuan mahasiswa memperoleh skor 832 dengan 1176 skor maksimal sehinggan hasil persentase berbilang 70,74\% yang dapat diartikan pada indikator peningkatan pemahaman belajar dikategorikan positif. Hasil analisis tersebut menjelaskan bahwasanya sebagian mahasiswa merasa bahwa dengan terbentuknya mata kuliah yang menerapkan model pembelajaran online memotivasi mereka semakin kreatif, mereka mampu nemukan masalah-masalah baru yang mengembangkan pengetahuan mahasiswa. (Nisa, 2012) manfaat dari pembelajaran online dapat memberi mahasiswa pengetahuan yang bermacam-macam, mahasiswa bisa melakukan eksperimen secara komputasi, mahasiswa dapat berdiskusi secara online hingga mendapatkan keinginan yang diharapkan.

Pada tabel 3 hasil analisis faktor pendukung dan penghambat motivasi belajar dalam pembelajaran online mahasiswa Teknologi Pendidikan diatas, pada indikator pemanfaatan waktu dalam belajar memperoleh skor 796 dengan 1176 skor maksimal sehinggan hasil persentase berbilang 67,26\% yang dapat diartikan pada indikator pemanfaatan waktu ketika belajar dikategorikan positif. Hasil analisis tersebut menjelaskan bahwasanya sebagian mahasiswa memanfaatkan waktu tidak sinkron dengan sasaran mahasiswa dalam proses pembelajaran online, mahasiswa sering menunda pengumpulan tugas setiap kali memiliki tugas untuk jarak pengumpulan yang panjang, mereka lebih sering memanfaatkan waktunya dengan hal lain sampai batas pengumpulan terakhir tugas hasil mereka kurang maksimal. (Putri, 2017) sesungguhnya peserta didik yang mempunyai keteraturan dan kedisiplinan untuk mempergunakan waktunya dengan efektif dan efisien dapat memajukan hasil belajarnya.

Pada tabel 3 hasil analisis faktor pendukung dan penghambat motivasi belajar dalam pembelajaran online mahasiswa diatas, pada indikator aspirasi mahasiswa dalam belajar memperoleh skor 754 dengan 1176 skor maksimal sehinggan hasil persentase berbilang 64,11\% yang dapat diartikan pada indikator aspirasi mahasiswa dalam belajar dikategorikan positif. Hasil analisis tersebut menjelaskan bahwasanya sebagian mahasiswa kurang setuju terdapatnya penerapan model pembelajaran online diseluruh mata kuliah. Yang demikian dapat disaksikan dari kemandirian mereka pada saat belajar masih kurang, mereka masih selalu membutuhkan pendidik atau dosen ketika belajar. Padahal pada pembelejaran online mahasiswa dilatih untuk mandiri saat belajar, (Riyana, 2019) pembelajaran online dapat diaplikaskan pada semua mata pelajaran atau mata kuliah setelah peserta didik lebih mandiri.

Pada tabel 3 hasil analisis faktor pendukung dan penghambat motivasi belajar dalam pembelajaran online mahasiswa diatas, pada indikator upaya dosen ketika mengajar memperoleh skor 1655 dengan 2352 skor maksimal sehingga hasil persentase berbilang 70,36\% yang dapat diartikan pada indikator upaya dosen dalam mengajar dikategorikan positif. Hasil analisis tersebut menjelaskan bahwasanya sebagian mahasiswa merasa saat proses mengajar dosen tidak hanya menggunakan pembelajaran secara formal, akan tetapi juga mengkombinasikan dengan mengaplikasikan model pembelajaran online seperti itu mahasiswa semakin memiliki niat dan rasa semangat dalam belajar. Menurut pembelajaran yang menggabungkan antara pembelajaran online dengan pembelajaran langsung (Sinaga et al., 2019) pembelajaran campuran dapat disebut dengan sebutan Blended Learning, dengan mengaplikasikan sistem pembelajaran tersebut menciptakan pembelajaran lebih luwes, tidak membosankan dan tidak monoton. 


\section{SIMPULAN}

Hasil pembahahasan mengenai penelitian motivasi belajar dan faktor pendukung dan penghambat motivasi belajar dalam pembelajaran online mahasiswa Teknologi Pendidikan angkatan 2017, mahasiswa memiliki motivasi belajar yang positif dengan didukung oleh faktor motivasi belajar yang positif juga. Hasil tersebut dapat disimpulkan bahwa tidak semua mahasiswa memiliki motivasi yang tinggi dalam mengikuti pembelajaran online, dengan dilihat dari faktor motivasi belajaranya juga belum tinggi. Semakin tinggi faktor pendukung motivasi belajar, akan semakin tinggi juga motivasi dalam diri mahasiswa untuk mengikuti pembelajaran online. Dengan demikian, motivasi belajar bisa ditingkatkan kembali dengan memperbaiki faktor motivasi belajar yang kurang mendukung.

\section{DAFTAR RUJUKAN}

Admaja, A., Kuswandi, D., \& Soepriyanto, Y. (2019). Pengembangan Multimedia Tutorial Untuk Guru Dalam Mengembangkan Software Tes Berbasis Komputer. JINOTEP (Jurnal Inovasi Dan Teknologi Pembelajaran) Kajian Dan Riset Dalam Teknologi Pembelajaran. https://doi.org/10.17977/um031v5i22019p063

Anggraeni, R., Sulton, S., \& Sulthoni, S. (2019). Pengaruh Multimedia Tutorial Terhadap Hasil Belajar Bahasa Indonesia. Jurnal Kajian Teknologi Pendidikan. https://doi.org/10.17977/um038v2i22019p096

Arifin, Y., Setyosari, P., \& Ulfa, S. (2018). Pengembangan Multimedia Interaktik Materi Sandi Morse dalam Kegiatan Ekstrakurikuler Kepramukaan bagi Siswa Kelas V. JKTP.

Armansyah., Sulton., \& Sulthoni. (2019). Multimedia Interaktif Sebagai Media Visualisasi Dasar-Dasar Animasi. Jurnal Kajian Teknologi Pendidikan. https://doi.org/10.17977/um038v2i32019p224

Djamarah, S. Bahri \& Zain, A. (2010). Strategi belajar mengajar. Jakarta, Indonesia: Rineka Cipta.

Hamalik. (2003). Proses Belajar Mengajar. Jakarta: PT. Bumi Aksara., 73.

Haryaningtias, D., Suyatna, A., \& Sesunan, F. (2013). Pengembangan Multimedia Interaktif Tutorial Menggunakan Pendekatan Kontekstual. Jurnal Pembelajaran Fisika Universitas Lampung.

Hasan, B., \& Hermanto, D. (2019). Pelatihan Pembuatan Media Pembelajaran Berbasis AutoPlay bagi Kelompok Kerja Guru Kecamatan Geger di Kabupaten Bangkalan. Abdihaz: Jurnal Ilmiah Pengabdian Pada Masyarakat. https://doi.org/10.32663/abdihaz.v1i2.981

Herdiyanto, D., Sulton, S., \& Praherdhiono, H. (2020). Pengembangan Multimedia Pembelajaran Interaktif pada Materi Tema Tanah bagi Siswa Tunagrahita. JKTP: Jurnal Kajian Teknologi Pendidikan. https://doi.org/10.17977/um038v3i12019p088

Humienny \& Berta. (2018). Interactive Multimedia Learning Environment For Geometrical Specification Indication \& Verification Rules. Procedia CIRP, 75, 161-166.

Istika, D., Ngadimun, N., \& Suyanto, E. (2014). Pengembangan Multimedia Tutorial Interaktif Microsoft Office Word. Jurnal Teknologi Informasi Komunikasi Pendidikan.

Lee, W. W., \& Owens, D. L. (2004). Multimedia-Based Instructional Design. In Pfeiffer. https://doi.org/10.1007/s13398-014-0173-7.2

Mayer, R. E. (2009). Multimedia Learning. In Multimedia Learning. https://doi.org/10.1017/cbo9780511811678

Muchammad Azwar Anas., Soepriyanto Y., Susilaningsih. (2013). Pengembangan Multimedia Tutorial Topologi Jaringan Untuk SMK Kelas X Teknik Komputer Dan Jaringan. JKTP Volume 1, Nomor 4, Desember 2018.

Niken Ariani, D. H. (2010). Pembelajaran Multimedia di Sekolah. In Jakarta: PT. Prestasi Pustakarya (p. 11)

Nurullah, A., Soepriyanto, Y., Sulton, S., \& Husna, A. (2019). Pengembangan Multimedia Pembelajaran Energi dalam Sistem Kehidupan. JKTP: Jurnal Kajian Teknologi Pendidikan. https://doi.org/10.17977/um038v2i42019p315 
Praherdhiono, H., \& Adi, E. P. (2008). Panduan Praktikum Multimedia. Malang: Fakultas Ilmu Pendidikan. Universitas Negeri Malang, 4.

Kemendikbud. (2020). Surat Edaran Mendikbud No 4 Tahun 2020 Tentang Pelaksanaan Kebijakan Pendidikan Dalam Masa Darurat Penyebaran Corona Virus Disease (Covid-19) - Pusdiklat Pegawai Kementerian Pendidikan dan Kebudayaan. https://Pusdiklat.Kemdikbud.Go.Id/.

Rachmadtullah, R., Zulela, M. S., \& Sumantri, M. S. (2018). Development Of Computer-Based Interactive Multimedia: Study On Learning In Elementary Education. International Journal of Engineering and Technology (UAE). https://doi.org/10.14419/ijet.v7i4.16384

Rochmad. (2012). Desain Model Pengembangan Perangkat Pembelajaran. Jurnal Kreano, 3(1), 14.

Rudiawan, D., Hamidah, I., \& Komaro, M. (2015). Pengaruh Multimedia Model Tutorial Terhadap Hasil Belajar Gambar 3 Dimensi Siswa SMK. Journal of Mechanical Engineering Education. https://doi.org/10.17509/jmee.v2i1.1150

Saifudin, M., Susilaningsih, S., \& Wedi, A. (2020). Pengembangan Multimedia Interaktif Materi Sumber Energi untuk Memudahkan Belajar Siswa SD. JKTP: Jurnal Kajian Teknologi Pendidikan. https://doi.org/10.17977/um038v3i12019p068

Sihkabuden. (2011). Media Pembelajaran. In Malang: Departemen Pendidikan Nasional Universitas Negeri Malang Fakultas Ilmu Pendidikan. (p. 1).

Sulistiyo, E., \& Alfan, M. (2015). Perbandingan Media Pembelajaran (AutoPlay Media Studio) Sebagai Alat Bantu Pembelajaran Memperbaiki CD Player Siswa Kelas XI di SMK Negeri 3 Surabaya. Jurnal Pendidikan Teknik Elektro.

Tala, S., \& Vesterinen, V. M. (2015). Nature of Science Contextualized: Studying Nature of Science with Scientists. Science and Education. https://doi.org/10.1007/s11191-014-9738-2

Trinawindu. (2016). Multimedia Interaktif untuk Proses Pembelajaran. Multimedia Interaktif Untuk Proses Pembelajaran. Jurnal Prabangkara., 19(23), 35-42.

Waldrip, B., Prain, V., \& Carolan, J. (2010). Using Multi-Modal Representations To Improve Learning In Junior Secondary Science. Research in Science Education. https://doi.org/10.1007/s11165-0099157-6

Wardani, S. K., Setyosari, P., \& Husna, A. (2019). Pengembangan Multimedia Tutorial Mata Pelajaran IPA Pokok Bahasan Sistem Tata Surya Kelas VII MTS Raudlatul Ulum. Jurnal Kajian Teknologi Pendidikan, 2(1), 23-29. 